\title{
PENGARUH RASIO BAHAN PENYALUT MALTODEKSTRIN, GUM ARAB, DAN SUSU SKIM TERHADAP KARAKTERISTIK FISIK DAN KIMIA MIKROKAPSUL OLEORESIN DAUN KAYU MANIS (Cinnamomum burmannii)
}

\author{
Physical and Chemical Characteristics of Cinnamon Leaf (Cinnamomum burmannii) Oleoresin Microcapsule \\ Encapsulated with Maltodextrin, Arabic Gum, and Skim Milk as Coating Material
}

\author{
Lia Umi Khasanah, Baskara Katri Anandhito, Titiek Rachmawaty, Rohula Utami, Godras Jati Manuhara \\ Jurusan Teknologi Hasil Pertanian, Fakultas Pertanian, Universitas Sebelas Maret, \\ J1. Ir. Sutami 36 A, Kentingan, Surakarta 57126 \\ Email: liaumikhasanah@yahoo.ac.id
}

\begin{abstract}
ABSTRAK
Penelitian ini bertujuan untuk mengetahui pengaruh bahan penyalut berupa maltodekstrin, gum arab dan susu skim terhadap karakteristik fisik dan kimia mikrokapsul oleoresin daun kayu manis dua tahap. Dalam penelitian ini dilakukan empat variasi bahan penyalut berupa maltodekstrin: gum arab: susu skim (2:0:4, 2:2:2, 0:4:2 dan 2:0:4). Karakteristik fisik yang diuji meliputi rendemen, kadar air, kelarutan dalam air, dan mikrostruktur. Karakteristik kimia mikrokapsul oleoresin daun kayu manis dua tahap terpilih yang diuji meliputi kadar sisa pelarut dan kadar senyawa aktif. Rancangan percobaan yang digunakan dalam penelitian ini adalah Rancangan Acak Lengkap (RAL) dengan satu faktor yaitu variasi rasio bahan penyalut. Hasil penelitian menunjukkan bahwa variasi rasio bahan penyalut berpengaruh signifikan terhadap rendemen dan kadar air, namun tidak berpengaruh secara signifikan terhadap parameter kelarutan dalam air. Hasil pengamatan mikrostruktur menunjukkan bahwa susu skim dalam jumlah yang lebih besar menghasilkan penampakan mikrostruktur yang lebih baik. Kadar sisa pelarut mikrokapsul terpilih terdapat pada rasio 2:0:4 yaitu sebesar 0 ppm. Mikrokapsul ini mengandung senyawa aktif berupa linalool, coumarin, 9-hexadecenoic acid, 1,8-cineole serta benzene (3,3 dimehyl buthyl).
\end{abstract}

Kata kunci: Oleoresin, daun kayu manis, maltodekstrin, gum arab, susu skim, bahan penyalut

\begin{abstract}
This research was aimed to determine the effect of rasio variation of coating materials which are maltodextrin: arabic gum : skim milk $(2: 0: 4) ;(2: 2: 2) ;(0: 4: 2)$ and $(2: 0: 4)$ on the physical characteristics of two-steps oleoresin microcapsule such as yield, moisture content, solubility in water and the microstructure; and to investigate the chemical characteristics of selected two-steps oleoresin microcapsule which were levels of residual solvent and active compounds. The experimental design used in this research was Completely Randomized Design(CRD) with one factor (rasio variation of coating materials). The results showed that the rasio variation of coating materials had significant effect on the yield and water content, but unsignificantly affected the solubility in water. The results of microstructure observation indicated that the presence of skim milk in larger quantity produced a better microstructure appearance. Residual solvent levels of selected microcapsule (maltodextrin : arabic gum : skimmilk $=2: 0: 4$ ) was 0 ppm and the active compound of selected microcapsule were linalool, coumarin, 9-hexadecenoic acid, 1.8-cineole and benzene (3.3 dimethlbuthyl).
\end{abstract}

Keywords: Oleoresin, cinnamon leaf, coating material, maltodextrin, arabic gum, skim milk 


\section{PENDAHULUAN}

Kayu manis merupakan salah satu tanaman yang digunakan sebagai rempah-rempah dan merupakan komoditi ekspor Indonesia yang cukup penting. Berdasarkan Daswir (2004) selama ini hanya kulit batang kayu manis yang sudah dimanfaatkan, sementara daunnya masih belum termanfaatkan bahkan dianggap tak bernilai. Upaya yang dapat dilakukan untuk meningkatkan nilai jual daun kayu manis adalah dengan melakukan proses penyulingan daun kayu manis menjadi minyak atsiri dan ekstraksi untuk mendapatkan oleoresin. Oleoresin adalah senyawa yang diperoleh dari hasil ekstraksi rempah menggunakan senyawa hidrokarbon pelarut. Oleoresin dapat diperoleh dari ekstraksi satu tahap, dua tahap dan multitahap. Ekstraksi satu tahap adalah ekstraksi dengan pelarut yang cukup sehingga semua zat terlarut (bahan aktif oleoresin) dapat terekstrak. Ekstraksi multitahap adalah ekstraksi dimana pelarut yang sama dipakai berulang-ulang sampai proses ekstraksi selesai. Ekstraksi dua tahap adalah pengabungan antara penyulingan dengan ekstraksi. Pada proses destilasi daun kayu manis penyulingan hanya mendapatkan komponen volatilnya yaitu berupa minyak atsiri daun kayu manis, sedangkan resin yang terkandung di dalam daun kayu manis belum terambil (Budi, 2009 dan Widjanarko, 2008). Menurut SAQA (2012) keuntungan pembuatan oleoresin daun kayu manis dengan ekstraksi dua tahap adalah mendapatkan oleoresin yang dapat dikontrol kadar minyak atsirinya karena adanya proses blending antara oleoresin hasil ekstraksi dengan minyak hasil penyulingan. Hasil blending antara oleoresin hasil ekstraksi ampas destilasi dengan minyak atsiri hasil penyulingan disebut sebagai oleoresin dua tahap.

Bentuk oleoresin mempunyai beberapa keuntungan yaitu aroma dan cita rasanya lebih kuat dari bahan mentahnya, stabil dalam penyimpanan, dan tidak membutuhkan tempat penyimpanan yang besar (Sari, 2010). Namun oleoresin memiliki konsistensi yang sangat pekat dan lengket, sehingga sulit ditangani dan dicampurkan serta sensitif terhadap cahaya, panas, dan oksigen. Metode mikroenkapsulasi merupakan perlakuan lanjutan untuk mengatasi kelemahan tersebut.

Mikroenkapsulasi merupakan teknologi penyalutan padatan, cairan dan gas oleh kapsul dalam bentuk mikro dimana kapsul tersebut dapat melepaskan isinya di bawah kondisi spesifik. Spray drying adalah metode tertua dan merupakan teknik enkapsulasi yang paling banyak digunakan di sektor industri makanan. Berdasarkan Gharsallaoui dkk. (2007) jenis bahan penyalut yang lazim digunakan adalah golongan gum, karbohidrat, dan protein. Gum arab dapat menghasilkan emulsi yang stabil. Penggunaan gum arab sebagai bahan penyalut dapat melindungi senyawa volatil dari oksidasi dan penguapan (Kanakdande dkk., 2007).
Karbohidrat seperti pati, maltodekstrin, merupakan bahan penyalut yang baik karena viskositasnya rendah pada padatan tinggi dan memiliki sifat kelarutan yang tinggi (Balasubramani dkk., 2014). Sementara protein seperti susu skim, whey dapat mengikat komponen flavor. Sebagai bahan penyalut, susu skim menghasilkan mikrokapsul dengan rendemen, kadar minyak atsiri, dan surface oil yang lebih tinggi (Nasrullah, 2010). Penelitian enkapsulasi flavor dengan menggunakan gum arab telah banyak dilakukan. Kanakdande dkk. (2007) menggunakan gum arab, maltodekstrin, dan pati termodifikasi yang telah dikomersilkan (Hi-cap) sebagai bahan penyalut oleoresin jintan. Kemudian Carniero dkk. (2013) menggunakan kombinasi maltodekstrin, whey, dan gum arab sebagai bahan penyalut minyak biji rami. Masingmasing bahan penyalut memiliki kekurangan dan kelebihan, sehingga perlu dilakukan variasi bahan penyalut untuk mendapatkan hasil yang optimal. Penggunaan rasio bahan penyalut yang berbeda juga bertujuan untuk mengetahui pengaruh masing-masing jenis bahan penyalut (golongan gum, karbohidrat, protein) terhadap karakteristik mutu mikrokapsul yang dihasilkan.

Tujuan penelitian ini adalah untuk mengetahui pengaruh variasi rasio bahan penyalut terhadap karakteristik fisik dan kimia mikrokapsul oleoresin daun kayu manis dua tahap. Dalam penelitian ini dilakukan empat variasi bahan penyalut berupa maltodekstrin: gum arab: susu skim (2:0:4, 2:2:2, 0:4:2 dan 2:0:4). Karakteristik fisik yang diuji meliputi rendemen, kadar air, kelarutan dalam air, dan mikrostruktur. Karakteristik kimia mikrokapsul oleoresin daun kayu manis dua tahap terpilih yang diuji meliputi kadar sisa pelarut dan kadar senyawa aktif.

\section{METODE PENELITIAN}

\section{Bahan}

Bahan yang digunakan dalam penelitian ini adalah daun kayu manis (Cinnamomum burmannii) yang diperoleh dari Desa Bubakan, Kecamatan Girimarto, Kabupaten Wonogiri. Destilasi daun kayu manis menggunakan pelarut air. Ekstraksi daun kayu manis menggunakan pelarut etanol teknis (kadar 70\%) merk Brataco diperoleh dari Toko Kimia Bratachem Surakarta. Bahan penyalut yang digunakan adalah maltodekstrin DE 10-15 merk Associated British Budi yang diperoleh dari Toko Kimia Bratachem Yogyakarta, gum arab diperoleh dari Toko Kimia Agung Jaya Surakarta, dan susu skim diperoleh dari Toko Aneka Kimia Malang. Bahan kimia yang digunakan untuk keperluan analisis yaitu aquades, heksana, dietil eter, natrium sulfat serta bahan yang digunakan untuk kromatografi gas. 


\section{Persiapan Daun Kayu Manis}

Daun kayu manis yang dipergunakan adalah daun kayu manis segar berwarna hijau tua, tidak cacat atau rusak. Daun kayu manis kemudian dikeringanginkan di atas jaring selama 5 hari (Nugraheni, 2012).

\section{Destilasi Daun Kayu Manis}

Setelah proses pengeringan, daun kayu manis dicacah kemudian dilanjutkan dengan proses penyulingan (destilasi). Metode penyulingan yang digunakan adalah metode penyulingan uap-air dilakukan selama 3 jam (Sundari, 2002).

\section{Ekstraksi Daun Kayu Manis Ampas Destilasi}

Ekstraksi diawali dengan pengeringan daun kayu manis ampas destilasi. Daun kayu manis ampas destilasi dikeringanginkan di atas jaring hingga kadar air mencapai 11-12\%. Ekstraksi dilakukan dengan cara maserasi pada suhu $78^{\circ} \mathrm{C}$ selama 5 jam 9 menit 26 detik (Uyun, 2013). Pelarut yang digunakan dalam proses ekstraksi daun kayu manis ampas destilasi adalah etanol $70 \%$ dengan perbandingan bahan dan pelarut 1 : 6 (Nurdjanah dkk., 1994). Setelah ekstraksi dilakukan penyaringan untuk memisahkan antara ampas dan filtrat ekstrak daun kayu manis ampas destilasi. Kemudian dilakukan penguapan pelarut etanol menggunakan rotary evaporator dalam keadaan vakum pada suhu $80^{\circ} \mathrm{C}$ dengan kecepatan $120 \mathrm{rpm}$. Proses ini dihentikan setelah pelarut etanol teruapkan semua (tidak ada lagi pelarut yang menetes), serta didapatkan oleoresin daun kayu manis ampas destilasi dalam bentuk pasta kental berwarna coklat kehijauan.

\section{Pembuatan Oleoresin Daun Kayu Manis Dua Tahap}

Oleoresin daun kayu manis dua tahap diperoleh dengan cara mencampurkan oleoresin daun kayu manis ampas destilasi yang diperoleh dari proses ekstraksi dengan minyak atsiri daun kayu manis hasil penyulingan.

\section{Mikroenkapsulasi Oleoresin Daun Kayu Manis Dua Tahap}

Larutan bahan penyalut yang digunakan dalam penelitian ini sebesar $500 \mathrm{ml}$. Proses pembuatan emulsinya yaitu bahan penyalut sebanyak 100 gr ditambahkan ke dalam aquades hingga didapatkan suspensi dengan total padatan $20 \%$. Terdapat empat formulasi bahan penyalut berupa maltodekstrin: gum arab: susu skim (2:0:4, 2:2:2, 0:4:2 dan 2:0:4). Kemudian dihomogenisasi menggunakan homogenizer (Ultra-Turax) secara perlahan-lahan dengan kecepatan putaran 8000 rpm selama 5 menit. Bahan penyalut yang ditambahkan ke dalam aquades dimasukkan sedikit demi sedikit dengan tujuan untuk mempermudah proses pencampuran. Setelah seluruh bahan penyalut tercampur merata, ditambahkan oleoresin daun kayu manis dua tahap $10 \%$ dari total larutan bahan penyalut (50 gr). Oleoresin yang dimasukkan juga ditambahkan secara perlahan dengan bantuan homogenizer. Homogenisasi antara bahan penyalut dan oleoresin dilakukan hingga semua bahan tercampur merata. Proses homogenisasi dilakukan selama \pm 15 menit. Campuran antara bahan penyalut dan oleoresin selanjutnya dikeringkan dengan spray dryer dengan suhu inlet $120^{\circ} \mathrm{C}$ dan suhu outlet $60^{\circ} \mathrm{C}$.

\section{Pengujian Rendemen dan Karakteristik Mutu Mikrokapsul Oleoresin Daun Kayu Manis Dua Tahap}

Setelah diperoleh mikrokapsul oleoresin daun kayu manis dua tahap, mikrokapsul tersebut diuji rendemen dan karakteristik mutunya. Analisis yang dilakukan meliputi rendemen (Gardjito dkk., 2006), kadar air (AOAC, 1997), kelarutan dalam air (Fardiaz dkk., 1992), pengamatan mikrostruktur (Trindade dkk., 2010).

\section{Pengujian Mikrokapsul Oleoresin Daun Kayu Manis Dua Tahap Terpilih}

Setelah dilakukan pengujian karakteristik mutu pada keseluruhan sampel akan diperoleh mikrokapsul oleoresin daun kayu manis dua tahap terpilih. Kemudian akan dilakukan uji kadar sisa pelarut (Pardosi, 2009) dan kadar senyawa aktif pada mikrokapsul oleoresin daun kayu manis dua tahap terpilih tersebut dengan menggunakan metode GCMS (Soottitantawat dkk., 2003).

\section{Rancangan Penelitian dan Analisis Data}

Penelitian ini menggunakan Rancangan Acak Lengkap (RAL) dengan satu faktor yaitu variasi rasio bahan penyalut. Pada penelitian ini dilakukan dua kali ulangan perlakuan dan satu kali ulangan analisis. Untuk mengetahui pengaruh variasi rasio bahan penyalut dilakukan analisis statistik menggunakan sidik ragam ANOVA dengan SPSS versi 17.0. Jika terdapat perbedaan maka dilanjutkan dengan Duncan Multiple Range Test (DMRT) pada $\alpha=0,05$.

\section{HASIL DAN PEMBAHASAN}

\section{Oleoresin Daun Kayu Manis Dua Tahap}

Oleoresin daun kayu manis dua tahap merupakan salah satu produk olahan daun kayu manis yang berbentuk cairan kental atau pasta yang didapatkan melalui proses destilasi dan maserasi. Dari proses destilasi diperoleh minyak atsiri daun kayu manis dengan rendemen sebesar 0,141\%. Daun kayu manis ampas destilasi selanjutnya diekstraksi untuk mendapatkan oleoresin daun kayu manis ampas destilasi. Kemudian dilakukan pencampuran antara oleoresin daun 
kayu manis ampas destilasi dengan minyak atsiri hasil penyulingan, menghasilkan oleoresin daun kayu manis dua tahap. Rendemen oleoresin daun kayu manis dua tahap sebesar 11,93\%. Hasil ini lebih kecil jika dibandingkan dengan penelitian yang telah dilakukan oleh Uyun (2013), rendemen oleoresin daun kayu manis yang dihasilkan sebesar $12,27 \%$. Menurut Sari (2010), ada beberapa faktor yang mempengaruhi rendemen dan mutu oleoresin yaitu ukuran dan jenis bahan, lama waktu pengontakan (lama waktu ekstraksi), jenis pelarut, konsentrasi pelarut, dan temperatur. Dalam penelitian ini diduga kondisi bahan baku yang berbeda kualitasnya (umur dan kesegaran daun) mempengaruhi rendemen oleoresin daun kayu manis yang diperoleh.

\section{Karakteristik Fisik Mikrokapsul Oleoresin Daun Kayu Manis Dua Tahap}

Tabel 1. Karakteristik fisik mikrokapsul oleoresin daun kayu manis dua tahap

\begin{tabular}{lccc}
\hline \multicolumn{1}{c}{ Sampel } & $\begin{array}{c}\text { Rendemen } \\
(\%)\end{array}$ & $\begin{array}{c}\text { Kadar air } \\
(\%)\end{array}$ & $\begin{array}{c}\text { Kelarutan dalam } \\
\text { air }(\%)\end{array}$ \\
\hline $\begin{array}{l}\text { Maltodekstrin : } \\
\text { Gum Arab : Susu }\end{array}$ & $14,339^{\mathrm{a}} \pm 1,623$ & $5,982^{\mathrm{b}} \pm 0,962$ & $98,067^{\mathrm{b}} \pm 0,134$ \\
Skim $(2: 4: 0)$ & & & \\
Maltodekstrin : & $22,770^{\mathrm{b}} \pm 2,235$ & $2,928^{\mathrm{a}} \pm 0,161$ & $95,616^{\mathrm{ab}} \pm 2,037$ \\
Gum Arab : Susu & & & \\
Skim $(2: 2: 2)$ & & & \\
Maltodekstrin : & $16,863^{\mathrm{a}} \pm 2,380$ & $3,522^{\mathrm{a}} \pm 0,054$ & $96,167^{\mathrm{ab}} \pm 1,095$ \\
Gum Arab : Susu & & & \\
Skim (0 : $4: 2)$ & & & \\
Maltodekstrin : & $23,559^{\mathrm{b}} \pm 1,259$ & $2,865^{\mathrm{a}} \pm 0,686$ & $94,444^{\mathrm{a}} \pm 0,439$ \\
Gum Arab : Susu & & & \\
Skim (2: $:$ : $)$ & & & \\
\hline
\end{tabular}

Keterangan : superscript yang sama pada kolom yang sama menunjukkan tidak beda nyata $(\mathrm{p}<0,05)$

Karakteristik fisik mikrokapsul oleoresin daun kayu manis dua tahap disajikan pada Tabel 1. Dalam proses mikroenkapsulasi, jumlah mikrokapsul yang diperoleh sangat ditentukan oleh viskositas emulsi campuran bahan sebelum mengalami pengeringan (Bhandari dkk., 1992). Sebelumnya pada penelitian ini telah dilakukan pengujian total padatan terlarut (TPT) untuk mengetahui karakteristik campuran suspensi. Diketahui bahwa sampel dengan rasio bahan penyalut maltodekstrin : gum arab : susu skim sebesar 2:4:0, 2:2:2, 0:4:2 dan 2:0:4 memiliki nilai TPT berturutturut sebesar $21,8^{\circ}$ Brix; $21,2^{\circ}$ Brix; $19,8^{\circ}$ Brix, dan $19,7^{\circ}$ Brix. Menurut Srihari, dkk. (2010) semakin banyak kandungan padatan terlarut maka semakin besar viskositas suatu larutan. Viskositas yang tinggi menyebabkan rendemen semakin menurun.
Sampel dengan rasio bahan penyalut 2:0:4 yang memiliki nilai TPT terendah memiliki nilai rendemen tertinggi sebesar $23,5586 \%$. Sementara sampel dengan rasio bahan penyalut 2:4:0 dengan nilai TPT tertinggi memiliki nilai rendemen terendah sebesar $14,3391 \%$. Adanya gum arab sebagai bahan penyalut menyebabkan pembentukan gel yang mengakibatkan viskositas meningkat. Viskositas yang tinggi menyebabkan pengeringan tidak berjalan sempurna sehingga lebih banyak mikrokapsul yang jatuh ke chamber spray dyer daripada ke cyclone yang berarti tidak terhitung sebagai rendemen, sehingga terjadi penurunan rendemen mikrokapsul pada rasio penyalut yang menggunakan gum arab dalam jumlah besar yaitu pada sampel dengan rasio penyalut 2:4:0 dan 0:4:2.

Kadar air merupakan parameter yang menentukan kualitas mikrokapsul. Kadar air yang rendah dapat mencegah tumbuhnya mikroba yang dapat merusak produk. Menurut Yuliani dkk. (2007) kisaran kadar air yang baik untuk produk mikrokapsul yang diperoleh dari spray drying sebesar 2-6\%. Kadar air mikrokapsul dipengaruhi oleh penggunaan bahan penyalut, dalam penelitian ini adalah maltodekstrin, gum arab, dan susu skim. Korelasi antara komposisi bahan penyalut terhadap kadar air juga dapat dikaitkan dengan kekentalan (viskositas) emulsi bahan penyalut. Viskositas yang tinggi akan menyebabkan kadar air produk mikroenkapsulasi menjadi tinggi.

Gardjito dkk. (2006) menyebutkan maltodekstrin memiliki berat molekul yang lebih rendah (kurang dari 4000) dan struktur molekul yang lebih sederhana sehingga dengan mudah air dapat diuapkan ketika proses pengeringan berlangsung. Sementara gum arab memiliki berat molekul yang lebih besar \pm 500.000 dan struktur molekul yang lebih kompleks sehingga ikatan dengan molekul air lebih kuat maka ketika proses pengeringan berlangsung molekul air sulit diuapkan dan membutuhkan energi penguapan yang lebih besar. Usmiati dkk. (2010) menambahkan semakin tinggi komposisi susu skim dalam bahan pengkapsul, semakin rendah kadar air mikrokapsul yang dihasilkan. Susu skim memiliki kadar air berkisar 3-7\%. Oleh karena itu, mikrokapsul yang menggunakan bahan penyalut susu skim memiliki kadar air mikrokapsul rendah. Hasil yang didapat sesuai dengan teori tersebut, dimana kadar air terbesar adalah sampel dengan rasio 2:4:0 sebesar 5,9821\%. Sementara sampel dengan rasio 2:0:4 memiliki kadar air terendah sebesar $2,8650 \%$.

Kelarutan dalam air merupakan parameter yang berhubungan dengan pelepasan bahan aktif pada pengaplikasian mikrokapsul. Mikrokapsul sebaiknya memiliki kelarutan yang tinggi dalam pelarut yang umum digunakan seperti air. Menurut Nasrullah (2010), kelarutan dalam air mikrokapsul oleoresin lada hitam yang baik adalah diatas 90\%. Mikrokapsul dengan rasio bahan penyalut 2:4:0 
memiliki kelarutan tertinggi sebesar 98,0669\%. Tingginya kelarutan mikrokapsul ini disebabkan adanya maltodekstrin. Maltodekstrin dapat larut dengan sempurna dalam air dingin, sehingga dapat melepaskan flavor secara tepat pada aplikasi tertentu (Kenyon, 1995). Faktor yang mempengaruhi tingkat kelarutan dalam air maltodekstrin adalah besarnya dextrose equivalency (DE). Badarudin (2006) menyatakan semakin tinggi nilai $\mathrm{DE}$, semakin baik pula tingkat kelarutannya. Menurut BeMiller dan Whistler (1996), gum arab juga memiliki kelarutan yang tinggi di dalam air, sehingga kombinasi keduanya dapat menghasilkan produk mikrokapsul dengan nilai kelarutan dalam air tinggi.

Adapun mikrokapsul dengan kelarutan terendah adalah mikrokapsul dengan rasio bahan penyalut 2:0:4 sebesar 94,4442\%. Menurut Usmiati, dkk. (2010) komposisi susu skim yang semakin banyak dalam bahan pengkapsul dengan pemanasan pada suhu tinggi menyebabkan penurunan tingkat kelarutan mikrokapsul. Protein susu dapat mengalami denaturasi pada suhu tinggi. Proses denaturasi yang berlebihan menyebabkan insolubilitasi, sehingga mempengaruhi sifat fungsional protein yaitu menurunnya tingkat kelarutan.

\section{Pengamatan Mikrostruktur Mikrokapsul}

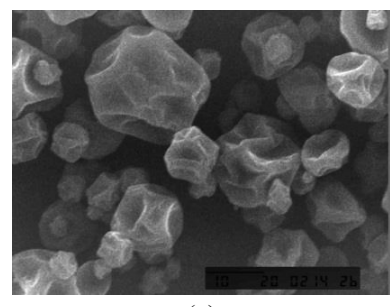

(a)

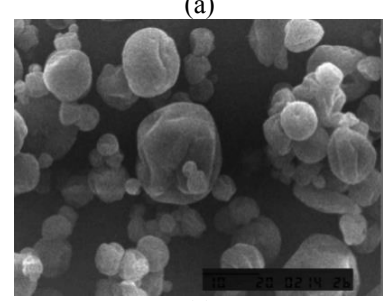

(c)

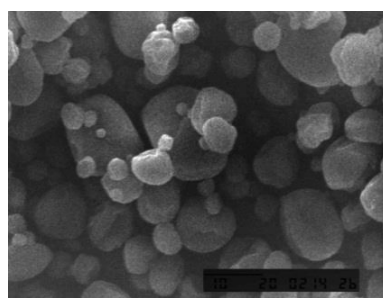

(b)

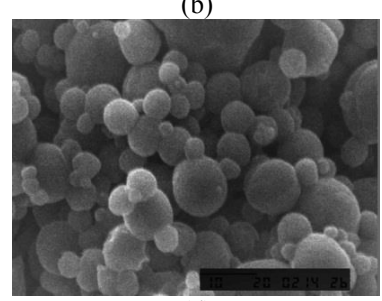

(d)
Gambar 1. Hasil pengamatan mikrostruktur mikrokapsul oleoresin daun kayu manis dua tahap dengan perbesaran 2000 kali (a) rasio bahan penyalut $2: 4: 0$, (b) $2: 2: 2$, (c) $0: 4: 2$, (d) $2: 0: 4$

Hasil mikrokapsul yang baik adalah berbentuk bulat tanpa kerutan yang berarti bahan aktif terkapsul dengan baik. Mikrokapsul dengan rasio penyalut 2:4:0 memiliki bentuk keriput yang lebih banyak (Gambar1.a). Hal ini diduga dikarenakan adanya maltodekstrin sebagai penyalut. Maltodekstrin sebagai penyalut tidak memiliki kemampuan yang baik sebagai pengemulsi. Sementara gum arab merupakan pengemulsi yang baik karena adanya komponen protein. Namun kemampuan emulsifikasi gum arab yang hanya memiliki kandungan protein $2 \%$ tidak sebaik kemampuan emulsifikasi protein susu seperti susu skim (Dickinson, 2003). Gambar 1.b merupakan mikrostruktur mikrokapsul dengan rasio penyalut 2:2:2.

Mikrostruktur mikrokapsul pada Gambar 1.b berbentuk bulat halus, meskipun masih terdapat beberapa mikrokapsul yang keriput. Hal ini diduga karena ketidakstabilan emulsi bahan penyalut. Maltodekstrin sebagai bahan penyalut memiliki sifat emulsi yang tidak stabil, sedangkan gum arab kemampuan emulsinya tidak sebaik susu skim. Sementara susu skim merupakan bahan penyalut berbasis protein dimana menurut Pahlevi, dkk. (2008) susu skim dapat berasosiasi dengan minyak dan air yang menyebabkan emulsi menjadi stabil. Meskipun telah ditambahkan susu skim sebagai pengemulsi namun jumlah yang ditambahkan sedikit sehingga belum mampu menstabilkan emulsi secara sempurna.

Gambar 1.c merupakan mikrostruktur mikrokapsul dengan rasio penyalut maltodekstrin: gum arab: susu skim (0 : $4: 2)$, jumlah mikrokapsul yang keriput lebih sedikit. Hal ini diduga karena susu skim cukup membuat emulsi menjadi stabil, namun jumlah yang ditambahkan lebih sedikit dibandingkan gum arab. Akibatnya masih terdapat mikrokapsul yang berbentuk keriput. Mikrokapsul dengan rasio penyalut maltodekstrin : gum arab : susu skim (2:0 : 4) memiliki mikrostruktur mikrokapsul berbentuk bulat utuh dengan permukaan yang halus (Gambar 1.d). Hal ini diduga dikarenakan adanya susu skim dalam jumlah yang lebih besar sebagai penyalut. Dalam hal ini susu skim berperan sebagai pengemulsi yang mampu menciptakan kestabilan emulsi yang baik pada larutan bahan penyalut. Hal ini mengakibatkan lapisan pelindung menjadi lebih tebal dan memiliki kemampuan menyalut bahan inti yang lebih baik (Murti, 2012).

Pada mikrostruktur mikrokapsul oleoresin daun kayu manis (Gambar 1) terdapat keretakan, pecah dan ada beberapa yang bentuknya mengempis. Hal ini diduga akibat peristiwa ballooning selama spray drying. Ballooning merupakan suatu peristiwa penggelembungan partikel mikrokapsul sebagai akibat pembentukan uap air di dalamnya saat proses spray drying. Penggelembungan ini dapat disebabkan oleh suhu spray drying yang terlalu tinggi atau ketidaksesuaian antara bahan pengkapsul dengan kondisi spray drying. Reineccius (1988), menyatakan bahwa ketika dinding kapsul tidak cukup kuat untuk menahan tekanan di dalam partikel mikrokapsul, dinding akan pecah dan partikel akan mengempis. Pengempisan ini dapat pula terjadi apabila tekanan di dalam mikrokapsul tidak cukup kuat ditahan oleh dinding kapsul. Ballooning dapat menyebabkan hilangnya komponen volatil dari dalam kapsul karena adanya keretakan pada partikel mikrokapsul. Keretakan dapat disebabkan suhu spray drying 
yang terlalu tinggi atau kekuatan fisik dinding kapsul yang lemah. Pada mikroenkapsul dengan rasio bahan penyalut 2:0:4 menghasilkan bentuk mikrostruktur yang terbaik yaitu berbentuk bulat utuh dengan permukaan yang halus. Estimasi ukuran mikrokapsul dengan rasio penyalut 2:4:0, 2:2:2, 0:4:2 dan 2:0:4 berturut-turut sebesar antara 4,615-20,769 $\mu \mathrm{m}$, 1,538-13,846 $\mu \mathrm{m}, 2,308-14,615 \mu \mathrm{m}$ dan 1,538-9,231 $\mu \mathrm{m}$.

\section{Mikrokapsul Oleoresin Daun Kayu Manis Dua Tahap Terpilih}

Mikrokapsul dengan rasio bahan penyalut 2:0:4 mempunyai rendemen tertinggi dibandingkan rasio lainnya sebesar 23,559\%, kadar air sebesar 2,8650\% memenuhi kisaran kadar air yang baik untuk produk mikrokapsul yang diperoleh dari spray drying sebesar 2-6\% (Yuliani dkk., 2007). Kelarutan dalam air mikrokapsul dengan rasio bahan penyalut 2:0:4 lebih rendah dibandingkan mikrokapsul dengan variasi rasio bahan penyalut lainnya sebesar 94,444\%. Menurut Nasrullah (2010), kelarutan dalam air untuk produk mikrokapsul yang baik adalah di atas $90 \%$, sehingga mikrokapsul dengan rasio bahan penyalut 2:0:4 tetap dipilih. Mikrostruktur mikrokapsul dengan rasio bahan penyalut 2:0:4 menghasilkan bentuk mikrokapsul yang paling baik, yaitu bulat utuh dengan permukaan halus. Mikrokapsul yang baik adalah berbentuk bulat tanpa kerutan yang berarti bahan aktif terkapsul dengan baik (Hasna, 2012). Mikrokapsul dengan rasio bahan penyalut 2:0:4 merupakan mikrokapsul oleoresin daun kayu manis dua tahap terpilih berdasarkan parameter rendemen, kadar air, kelarutan dalam air dan mikrostuktur.

\section{Karakteristik Mikrokapsul Oleoresin Daun Kayu Manis Dua Tahap Terpilih}

Sisa pelarut oleoresin diharapkan dalam jumlah yang rendah seperti yang disyaratkan FDA. Menurut FDA batasan sisa pelarut etanol yang diperbolehkan untuk produk pangan adalah sebesar 30 ppm (Nurdjanah dkk., 1994). Kadar sisa pelarut etanol pada mikrokapsul oleoresin daun kayu manis dua tahap terpilih sebesar 0 ppm. Tidak adanya sisa pelarut etanol pada penelitian ini menunjukkan bahwa proses pengolahan oleoresin menjadi mikrokapsul dengan

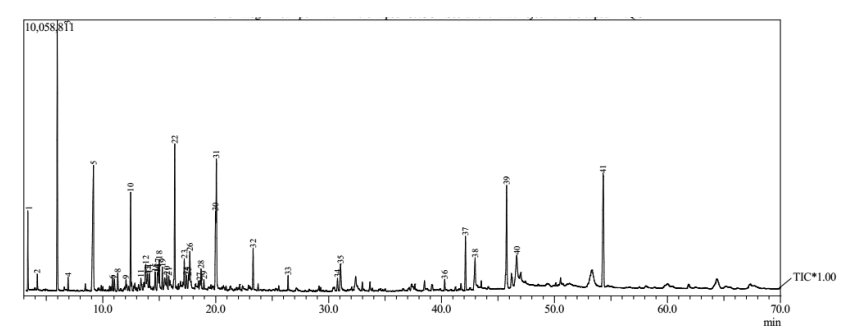

Gambar 2. Kromatogram GC-MS mikrokapsul oleoresin daun kayu manis dua tahap terpilih metode spray drying dapat menghilangkan pelarut etanol. Hal ini dikarenakan penggunaan suhu inlet yang cukup tinggi $\left(120^{\circ} \mathrm{C}\right)$, sehingga dapat menyebabkan sisa pelarut (etanol) ikut teruapkan.

Tabel 2. Komponen senyawa-senyawa penyusun mikrokapsul oleoresin daun kayu manis dua tahap terpilih

\begin{tabular}{|c|c|c|c|c|}
\hline Puncak ke- & $\begin{array}{l}\text { Waktu } \\
\text { retensi }\end{array}$ & Area & Persentase & Nama \\
\hline \multirow[t]{2}{*}{7} & 20,058 & & 39,80 & Linalool \\
\hline & & 18919391 & & \\
\hline 9 & 31,055 & 5690626 & 11,97 & Coumarin \\
\hline 11 & 46,663 & 5231269 & 11,19 & 9-Hexadecenoic Acid \\
\hline 6 & 17,708 & 4495224 & 9,46 & 1,8-Cineole \\
\hline 1 & 11,321 & 2473386 & 5,20 & Benzene (3,3 \\
\hline & & & & dimethyl butyl) \\
\hline 2 & 13,967 & 2467738 & 5,19 & $\alpha$-Pinene \\
\hline 8 & 30,784 & 1918715 & 4,04 & Cinnamyl Acetate \\
\hline 4 & 17,400 & 1660248 & 3,49 & $\rho$-Cymene \\
\hline 10 & 40,277 & 1593612 & 3,35 & Neophytadiene \\
\hline 3 & 15,675 & 1548880 & 3,26 & $\beta$-Pinene \\
\hline 5 & 17,583 & 1446083 & 3,04 & L-Limonene \\
\hline
\end{tabular}

Pada Gambar 2 dan Tabel 2 terlihat bahwa komponen kimia mayor yang terdeteksi meliputi linalool, coumarin, 9-hexadecenoic acid, 1,8-cineole serta benzene (3,3 dimehyl buthyl). Adapun komponen kimia minornya meliputi a-pinene, cinnamyl acetat dan sebagainya. Sebelumnya Singh, dkk. (2007) menemukan komponen mayor dalam minyak atsiri daun kayu manis meliputieugenol (87,3\%), bicyclogermacrene, $\alpha$-phellanderene, $\quad \beta$-carryophyllene, aromadendrene, $\rho$-cymene, dan 1,8-cineole. Adapun dalam oleoresin daun kayu manis terkandung eugenol, spathulenol, bicyclogermacrene, $\beta$-carryophyllene, serta $\delta$-elemene. Menurut Thomas dan Duethi (2012), minyak daun kayu manis terdiri dari eugenol (80-88\%), cinnamaldehyde, cinnamyl acetate, pinene, linalool, eugenol acetate, dan senyawa minor lainnya. Senyawa terbesar pada mikrokapsul oleoresin daun kayu manis dua tahap terpilih adalah linalool. Linalool termasuk senyawa terpenoid alkohol, berbentuk cair, tidak berwarna, beraroma wangi dan mempunyai rumus empiris $\mathrm{C}_{10} \mathrm{H}_{18} \mathrm{O}$, serta rumus struktur 3,7 dimetil 1,6 oktadien-3-ol. Linalool merupakan senyawa alkohol rantai lurus. Senyawa linalool merupakan komponen yang menentukan intensitas aroma harum (Handayani dan Juniarti, 2012).

Berbedanya jumlah dan senyawa yang terkandung dalam daun kayu manis disebabkan karena adanya faktor eksternal yaitu kondisi dan daerah tumbuh tanaman kayu manis yang menyebabkan perbedaan kandungan kimianya. Selain faktor eksternal tersebut keragaman dalam sifat-sifat 
minyak murni ini tergantung sebagian besar kepada keadaan bahan baku dan umur bahan baku (Khasanah dkk., 2014).

\section{KESIMPULAN}

Variasi rasio bahan penyalut maltodekstrin: gum arab: susu skim (2:0:4, 2:2:2, 0:4:2 dan 2:0:4) memberikan pengaruh yang signifikan terhadap karakteristik mikrokapsul oleoresin daun kayu manis dua tahap yang meliputi rendemen dan kadar air, namun dinyatakan tidak berpengaruh secara signifikan terhadap karakteristik lainnya yaitu kelarutan dalam air. Mikrostruktur mikrokapsul oleoresin daun kayu manis dua tahap dengan variasi rasio bahan penyalut 2:0:4 memberikan bentuk yang lebih baik dibandingkan variasi bahan penyalut lain yaitu bulat utuh dengan permukaan halus. Mikrokapsul oleoresin daun kayu manis dua tahap dengan variasi rasio bahan penyalut 2:0:4 merupakan mikrokapsul terpilih. Kadar sisa pelarut etanol mikrokapsul oleoresin daun kayu manis dua tahap terpilih sebesar 0 ppm dengan kandungan senyawa aktif mayor adalah linalool $(39,80 \%)$, coumarin $(11,97 \%)$, 9-hexadecenoic acid(11,19\%), 1,8-cineole (9,46\%), serta benzene (3,3 dimehyl buthyl) (5,20\%).

\section{UCAPAN TERIMA KASIH}

Peneliti mengucapkan terima kasih kepada Universitas Sebelas Maret Surakarta yang telah membiayai penelitian ini melalui Skim Hibah Pusat Keunggulan PNBP UNS Tahun Anggaran 2014 dengan judul "Pemanfaatan Lanjut Flavor Eksotis Produk Generasi Satu Hasil Pengolahan Terintegrasi Kayu Manis (Cinnamomum burmanii)" dengan nomor dan tanggal kontrak penelitian 501/UN27.11/PN/2014 tanggal 16 Juni 2014.

\section{DAFTAR PUSTAKA}

AOAC. (1997). Method of Analysis of Association of Official Analytical Chemist. Washington DC.

Badarudin (2006). Optimalisasi Ekstraksi Komponen Bioaktif Daun Tabat Barito (Ficus deltoida). Skripsi. Jurusan Teknologi Pangan dan Gizi. Fakultas Teknologi Pertanian. Institut Pertanian Bogor, Bogor.

Balasubramani, P., Palaniswamy, P.T., Visvanathan, R., Thirupathi, V., Subbayaran, A. dan Maran, J.P. (2014). Microencapsulation of garlic oleoresin using maltodextrin as wall material by spray drying technology. International Journal of Biological Macromolecules 72: 210-217.
Bhandari, B.R., Dumoulin, E.D., Richard, H.M.J., Noleau, I. dan Lembert, A.M. (1992). Flavour encapsulation by spray drying: application to citral and linalyl acetat. Journal of Food Science 57(1): 217-221.

Budi, F.S. (2009). Pengambilan Oleoresin dari Ampas Jahe (Hasil Samping Penyulingan Minyak Jahe) dengan Proses Ekstraksi. Jurnal Teknik 30(3): 156-161.

Daswir (2004). Profil tanaman kayu manis di Indonesia (Cinnamomum spp.). Balai Penelitian Tanaman Obat dan Aromatik 1: 46-54.

Dickinson, E. (2003). Hydrocolloids at interfaces and the influence on the properties of dispersed systems. Food Hydrocolloids 17: 25-39.

Fardiaz, D., Andarwulan, N., Wijaya, H. dan Puspitasari, N.L. (1992). Petunjuk Praktikum Teknik Analisa Sifat Kimia dan Fungsional Komponen Pangan. IPB Press, Bogor.

Gardjito, M., Murdiati, A. dan Aini, N. (2006). Mikroenkapsulasi $\beta$-karoten buah labu kuning dengan enkapsulan whey dan karbohidrat. Jurnal Teknologi Pertanian 2(1): 13-18.

Gharsallaoui, A., Roudaut, G., Chambin, O., Voilley, A. dan Saurel, R. (2007). Review: Applications of spray drying in microencapsulation of food ingredients: an overview. Food Research International 40: 1107-1121.

Handayani, P.A. dan Juniarti, E.R. (2012). Ekstraksi minyak ketumbar (coriander oil) dengan pelarut etanol dan n-heksana. Jurnal Bahan Terbarukan 1(1): 1-7.

Hasna, T. (2012). Pengaruh Variasi Rasio Bahan Penyalut Maltodekstrin dan Whey terhadap Karakteristik Mutu Mikroenkapsulan Oleoresin Kayu Manis (Cinnamomum burmanii). Skripsi. Jurusan Teknologi Hasil Pertanian. Fakultas Pertanian. Universitas Sebelas Maret Surakarta, Surakarta.

Kanakdande, D., Bhosale, R. dan Singhal, R.S. (2007). Stability cumin oleoresin microencapsulated in different combination of gum arabic, maltodextrin, and modified starch. Carbohydrate Polymer 67: 536-541.

Khasanah, L.U., Utami, R., Anandhito, B.K. dan Nugraheni, A.E. (2014). Pengaruh perlakuan pendahuluan fermentasi padat dan fermentasi cair terhadap rendemen dan karakteristik mutu minyak atsiri daun kayu manis. Agritech 34(1): 36-42.

Kenyon, M.M. (1995). Modified starch, maltodextrin, corn syrup solid as wall materials for food encapsulation. Dalam: Risch, S.J. dan Reineccius, G.A. (Eds). Encapsulation and Control Release of Food Ingredients, hal. 590. ACS symposium series. 
Murti, L.W. (2012). Pengaruh Variasi Rasio Bahan Penyalut Gum Arab dan Maltodekstrin terhadap Karakteristik Mutu Mikroenkapsulan Oleoresin Kayu Manis (Cinnamomum burmanii). Skripsi. Jurusan Teknologi Hasil Pertanian. Fakultas Pertanian. Universitas Sebelas Maret Surakarta, Surakarta.

Nasrullah, F. (2010). Pengaruh Komposisi Bahan Pengapsul Terhadap Kualitas Mikrokapsul Oleoresin Lada Hitam (Piper ningrum L.). Skripsi. Departemen Ilmu dan Teknologi Pangan. Fakultas Teknologi Pertanian. Institut Pertanian Bogor, Bogor.

Nugraheni, K.S. (2012). Pengaruh Perlakuan Pendahuluan dan Metode Destilasi Terhadap Karakteristik Mutu Minyak Atsiri Daun Kayu Manis (Cinnamomum Leaf Oil burmannii). Skripsi. Jurusan Teknologi Hasil Pertanian. Fakultas Pertanian. Universitas Sebelas Maret Surakarta, Surakarta.

Nurdjanah, N., Wiranatakusumah, dan Kusumawardhana. (1994). Oleoresin extraction and esssential oil distillation of ginger. Journal of Spices and Medicinal Crops 3(1): 12-21.

Pahlevi, Y.W., Estiasih, T. dan Saparianti, E. (2008). Mikroenkapsulasi ekstrak karoten dari spora kapang oncom merah (Neurospora sp.) dengan bahan penyalut berbasis protein menggunakan metode pengeringan semprot. Jurnal Teknologi Pertanian 9(1): 31-39.

Pardosi, J.L. (2009). Perbandingan Metode Kromatografi Gas dan Berat Jenis Pada Penetapan Kadar Etanol. Skripsi. Jurusan Kimia. Fakultas Matematika dan Ilmu Pengetahuan Alam. Universitas Sumatera Utara, Medan.

SAQA (2012). National certificate: paprika oleoresin extraction and blending. South African Qualifications Authority. http://www.saqa.org.za. [21 April 2014].

Sari, E. (2010). Optimasi kinerja alat ekstraksi dalam percobaan oleoresin kulit kayu manis pada skala pilot plant. Jurnal Ekotrans 10(10): 108.
Singh, G., Maurya, S., deLampasona, M.P. dan Catalan, C.A.N. (2007). A comparison of chemical, antioxidant, and antimicrobial studies of cinnamon leaf and bark volatile oils, oleoresins, and theirs constituents. Food and Chemical Toxicology 45: 11650-1661.

Soottitantawat, A., Yoshii, H., Furuta, T., Ohkawara, M. dan Linko, P. (2003). Microencapsulation by spray drying: influence of emulsion size on the retention of volatile compounds. Food Engeneering and Physical Properties 68: $2256-2262$.

Sundari, E. (2002). Pengambilan Minyak Atsiri dan Oleoresin dari Kulit Kayu Manis. Tesis. Departemen Teknik Kimia Program Pascasarjana. Institut Teknologi Bandung, Bandung.

Thomas, J. dan Duethi, P.P. (2012). Cinnamon. Handbook of Herbs and Spices (Second Edition) 10: 182-196.

Trindade, C.S.F., Santana, A.S., Monterrey-Quintero, E.S., Trinadade, M.A. dan Netto, F.M. (2010). The use of spray drying technology to reduce bitter taste of casein hydrolysate. Food Hydrocolloids 24: 336-340.

Usmiati, S., Yuliani, S. dan Noor, E. (2010). Aktivitas hambat terhadap bakteri patogen oleh serbuk bakteriosin asal Lactobacillus sp. galur SCG 1223. Jurnal Teknologi Industri Pertanian 21(4): 102-112.

Uyun, Q. (2013). Karakterisasi Oleoresin Daun Kayu Manis (Cinnamomum burmannii) Dengan Ekstraksi Dua Tahap Pada Rendemen Optimum. Skripsi. Jurusan Teknologi Hasil Pertanian. Fakultas Pertanian. Universitas Sebelas Maret Surakarta, Surakarta.

Widjanarko, S.B. (2008). Ekstraksi Oleoresin atau Bahan Aktif Tumbuhan dengan Pelarut. http://simonbwidjanarko. wordpress.com. [12 Juli 2014].

Yuliani, S., Desmawarni, Harimurti, N. dan Yuliani, S.S. (2007). Pengaruh laju alir umpan dan suhu inlet spray drying pada karakteristik mikrokaspul oleoresin jahe. Jurnal Pascapanen 4(1): 18-26. 